\title{
ANALISIS DAN RANCANG BANGUN SISTEM KERJA LINK PADA MESIN GERGAJI RADIAL 4 ARAH
}

\author{
Richard Kurniawan, Michael Wijaya, Didi Widya Utama dan Agus Halim \\ Program Studi Teknik Mesin, Fakultas Teknik Universitas Tarumanagara \\ e-mail: richardkurniawan098@gmail.com
}

\begin{abstract}
Four directions radial chainsaw is a chainsaw that have four cutting tools with link as it's power continuer and using roller chain transmission. This machine is designed to improve the efficiency of cutting time. Especially in the furniture industry. Still, the stacking of wood cutting work can reduce the production capabilities. This essay will discussed about the link and transmission working system that is used in the machine. The method used in this design is VDI 2221. The order of this design is starting from the calculation of the force that required to cut the wood, the force that contains in the link, and the calculation of motor horsepower that is required. The wood used is falcate which is a four strong class wood with split firmness by 3,64 $\frac{\mathrm{kg}}{\mathrm{mm}}$ and the dimension by $50 \mathrm{~mm} \times 50 \mathrm{~mm} \times 600 \mathrm{~mm}$. This machine is expected to cut all types of wood with maximum of split firmness by 3,64 $\frac{\mathrm{kg}}{\mathrm{mm}}$ and the limit of the wood dimensions that have been determined.
\end{abstract}

Keywords: Four directions radial chainsaw, link, motor horsepower, split firmness.

\begin{abstract}
Abstrak: Mesin gergaji radial empat arah adalah mesin gergaji yang mempunyai mata potong sebanyak empat buah dengan link sebagai penerus daya ke gergaji dan menggunakan transmisi jenis rantai. Mesin ini dirancang dengan tujuan untuk meningkatkan efisiensi waktu pemotongan. Terutama pada industri mebel. Menumpuknya pekerjaan memotong kayu dapat mengurangi kemampuan produksi. Dalam perancangan ini, akan dibahas sistem kerja link dan transmisi yang digunakan. Metode yang digunakan pada perancangan ini adalah metode VDI 2221. Tahapan perancangan yang dilakukan dimulai dari perhitungan gaya yang dibutuhkan untuk memotong kayu, gaya yang terjadi pada link, dan berakhir pada penentuan daya motor yang dibutuhkan. Kayu yang digunakan adalah kayu sengon yang merupakan kayu kelas kuat empat dengan keteguhan belah 3,64 $\frac{\mathrm{kg}}{\mathrm{mm}}$ dan dimensi kayu 50mm x 50mm $x$ $600 \mathrm{~mm}$. Mesin ini diharapkan dapat memotong segala jenis kayu dengan keteguhan belah maksimal 3,64 $\frac{\mathrm{kg}}{\mathrm{mm}}$ dan batasan dimensi yang telah ditentukan.
\end{abstract}

Kata Kunci: mesin gergaji radial empat arah, link, daya motor, keteguhan belah.

\section{PENDAHULUAN}

Seiring berkembangnya zaman, semakin banyak pula penemuan terhadap alat baru terutama di bidang permesinan. Kebutuhan dan ketergantungan manusia akan alat pun semakin meningkat. Menumpuknya pekerjaan merupakan salah satu faktor penghambat tingkat produktivitas seseorang dalam menyelesaikan pekerjaannya.

Salah satu peralatan yang digunakan dalam industri mebel adalah gergaji. Pada awalnya pemotongan kayu dilakukan secara manual dengan memanfaatkan tenaga manusia kemudian berubah menggunakan mesin gergaji. Dengan perkembangan zaman yang semakin maju, penggunaan gergaji tangan sudah mulai jarang digunakan dan beralih ke mesin gergaji. Dilihat dari sisi waktu, pemotongan kayu menggunakan mesin gergaji akan meningkatkan efisiensi dibanding menggunakan gergaji tangan. Hal ini dikarenakan pekerja dapat melakukan pekerjaan lain sambil menunggu proses pemotongan selesai.

Mesin gergaji pada umumnya hanya mempunyai satu mata potong untuk memotong benda kerja. Hal ini sangat membatasi kapasitas produksi dari mesin gergaji. Dalam dunia perindustrian mebel, tentu saja hal ini dapat memotong kapasitas produksi pemotongan kayu dan menurunkan efisiensi pekerja. Jumlah mata potong dapat ditingkatkan untuk meningkatkan kapasitas produksi dari mesin gergaji ini. Maka dari itu, mesin gergaji radial empat arah ini sangat berguna untuk meningkatkan efisiensi dan meminimalkan waktu kerja. 


\section{METODE PERANCANGAN}

Perancangan dengan menggunakan metode VDI 2221 (Verein Deutcher Ingenieure) merupakan salah satu metode untuk menyelesaikan permasalahan dan mengoptimalkan penggunaan material, teknologi dan keadaan ekonomi. Ide dan pengetahuan merupakan sumber dasar dari perancangan produk guna memenuhi permintaan konsumen dan demi keuntungan semua pihak tentunya.

Tabel 1. Daftar Spesifikasi Awal

\begin{tabular}{|c|c|c|}
\hline Parameter & Spesifikasi & Demand (D) / Wish (W) \\
\hline \multirow{4}{*}{ Geometri } & Dimensi Perancangan & $\mathrm{W}$ \\
\hline & Panjang & W \\
\hline & Lebar & W \\
\hline & Tinggi & $\mathrm{W}$ \\
\hline \multirow{3}{*}{ Gaya } & Kekakuan yang tinggi & $\mathrm{D}$ \\
\hline & Titik berat yang tepat & $\mathrm{D}$ \\
\hline & Bentuk rancangan hemat material & $\mathrm{D}$ \\
\hline \multirow{2}{*}{ Energi } & Energi berasal dari motor & $\mathrm{D}$ \\
\hline & Efisiensi energi tinggi & $\mathrm{D}$ \\
\hline \multirow{3}{*}{ Material } & Memiliki tingkat aus yang tinggi & $\mathrm{D}$ \\
\hline & Material mudah didapat & $\mathrm{D}$ \\
\hline & Material tahan lama & $\mathrm{D}$ \\
\hline Ergonomi & Bentuk proporsional & $\mathrm{W}$ \\
\hline Perakitan & Mudah untuk dibongkar pasang & $\mathrm{D}$ \\
\hline Biaya produksi & Biaya pembuatan cukup murah & $\mathrm{W}$ \\
\hline
\end{tabular}

Setelah membuat daftar spesifikasi awal, prinsip solusi sub fungsi perlu dibuat untuk menyeleksi komponen yang akan digunakan pada perancangan mesin gergaji radial 4 arah. Prinsip solusi ini dapat dibuat sebanyak yang diinginkan dengan tujuan menghasilkan produk dengan nilai efisien yang tinggi.

Tabel 2. Prinsip solusi sub fungsi

\begin{tabular}{|c|c|c|c|c|}
\hline \multirow[b]{2}{*}{ No } & \multicolumn{2}{|l|}{ Prinsip Solusi } & \multirow[b]{2}{*}{2} & \multirow[b]{2}{*}{3} \\
\hline & Sub Fungsi & 1 & & \\
\hline 1 & Penggerak & $\begin{array}{c}\text { Motor Listrik } \\
\text { AC }\end{array}$ & $\begin{array}{l}\text { Motor Listrik } \\
\text { DC }\end{array}$ & \\
\hline 2 & Penerus Daya & Sabuk \& Puli & $\begin{array}{l}\text { Rantai \& } \\
\text { Sproket }\end{array}$ & \\
\hline 3 & Mata Gergaji & Belah & Potong & \\
\hline 4 & Reduksi Putaran Motor & Sproket & Wormgear & Spur Gear \\
\hline 5 & Bentuk Material & Silinder Pejal & Angle Bar & Hollow Bar \\
\hline 6 & Material Rangka & Aluminiun & Besi & Baja \\
\hline 7 & Sistem Penggergajian & Satu Arah & Bolak - Balik & \\
\hline
\end{tabular}

Setelah prinsip solusi sub fungsi dibuat, langkah selanjutnya membuat kombinasi yang mungkin sehingga membentuk sistem yang paling menunjang dalam membentuk beberapa varian. 
Tabel 3. Kombinasi prinsip solusi sub fungsi

\begin{tabular}{|c|c|c|c|c|}
\hline No & Sub Fungsi & 1 & 2 & 3 \\
\hline 1 & Penggerak & Metor Listrik & $\begin{array}{l}\text { Motor Listrik } \\
\text { DC }\end{array}$ & \\
\hline 2 & Penerus Daya & Sabuk \& Puly & $\begin{array}{l}\text { Rantai \& } \\
\text { Sproke }\end{array}$ & \\
\hline 3 & Mata Gergaji & Belah & Potong & \\
\hline 4 & Reduksi Putaran Motor & Sproket $\downarrow$ & Wo & Spur Gear \\
\hline 5 & Bentuk Material & Silinder Pejal & Angle Bar & Hollow Bar \\
\hline 6 & Material Rangka & Aluminiun & Besi & Baja \\
\hline 7 & $\begin{array}{l}\text { Arah Gerakan } \\
\text { Penggergajian }\end{array}$ & Satu $f$ & & \\
\hline
\end{tabular}

Berdasarkan prinsip-prinsip solusi yang telah dilakukan di atas, dapat diperoleh beberapa pilihan, yaitu sebagai berikut:

1. V1: $1.2 \sim 2.1 \sim 3.2 \sim 4.3 \sim 5.3 \sim 6.3 \sim 7.1$

2. V2: $1.1 \sim 2.2 \sim 3.1 \sim 4.1 \sim 5.1 \sim 6.2 \sim 7.2$

3. V3: $1.1 \sim 2.2 \sim 3.2 \sim 4.2 \sim 5.3 \sim 6.2 \sim 7.2$

Untuk menentukan varian yang mungkin dilanjutkan dalam proses perancangan ini, harus dilakukan seleksi terhadap varian yang ada. Salah satu cara dalam pemilihan varian dapat dilakukan dengan menggunakan diagram seleksi seperti pada Tabel 4.

Dari Tabel 4, varian 2 dan 3 memenuhi kriteria perancangan. Dengan memperhitungkan sisi ergonomi, biaya produksi, dan sesuai fungsi yang dikehendaki untuk "mesin gergaji radial 4 arah" ini, maka dipilih varian 3 yang akan dilanjutkan ke proses berikutnya. Varian 3 terdiri dari penggerak berupa motor listrik AC, penerus daya berupa rantai dan sproket, mata gergaji berupa mata gergaji potong, wormgear untuk mereduksi putaran motor, hollow bar sebagai material rangka, dan arah gerakan bolak - balik dalam penggergajian.

Pengecekan perhitungan dibutuhkan untuk mengetahu apakah terdalat kesalahan dalam mendesain produk. Apabila perhitungan sudah sesuai dengan desain produk, maka hal yang dilakukan selanjutnya adalah pembuatan komponen termasuk di dalamnya : sistem transmisi rantai, poros, piringan, rel, ragum, dan plat untuk bearing. Ketika komponen sudah mencukupi, hal selanjutnya yang dilakukan adalah perangkaian produk. Uji coba alat dilakukan untuk mengetahui apakah mesin gergaji berjalan dengan lancar. 
Tabel 4. Pemilihan varian solusi

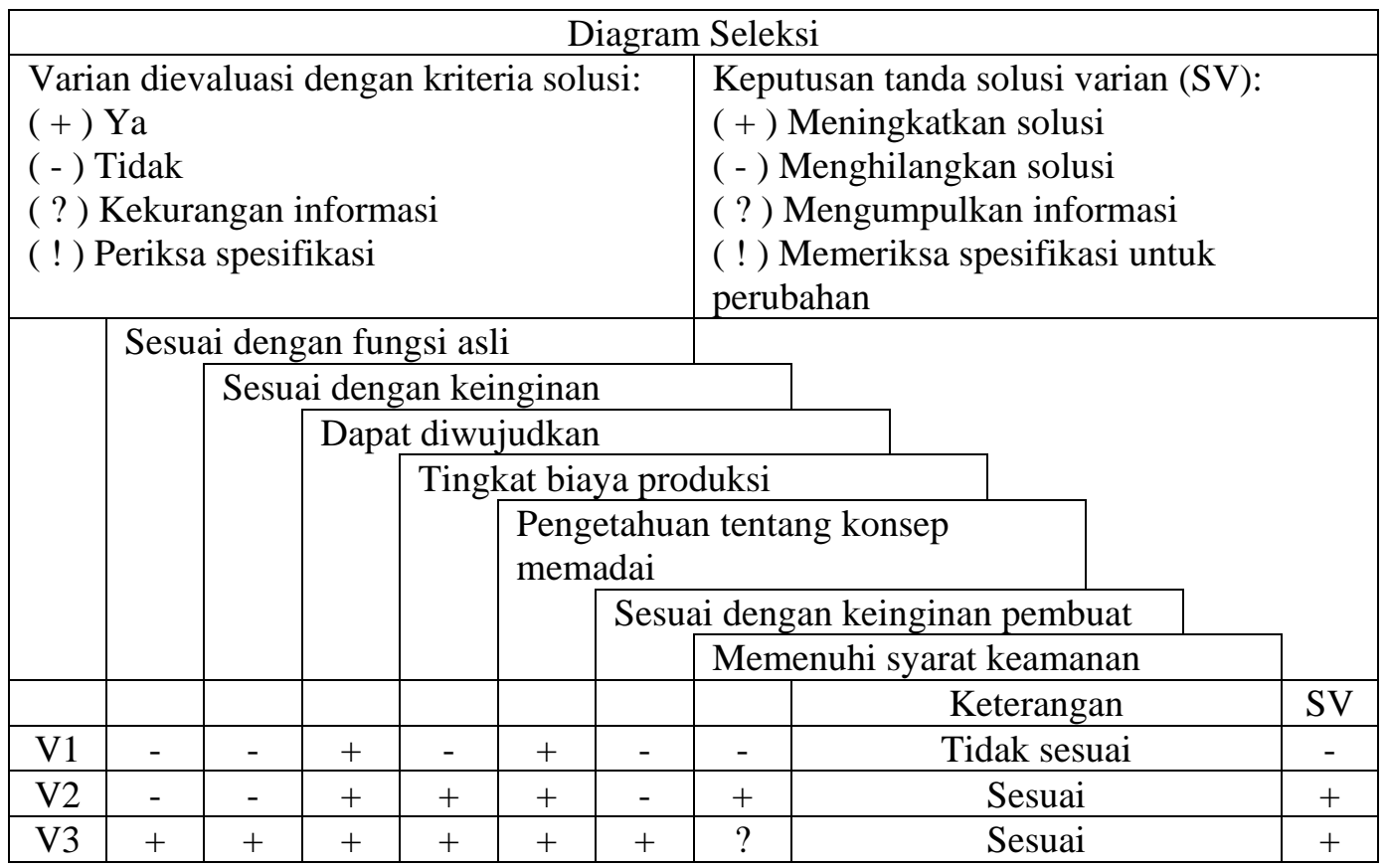

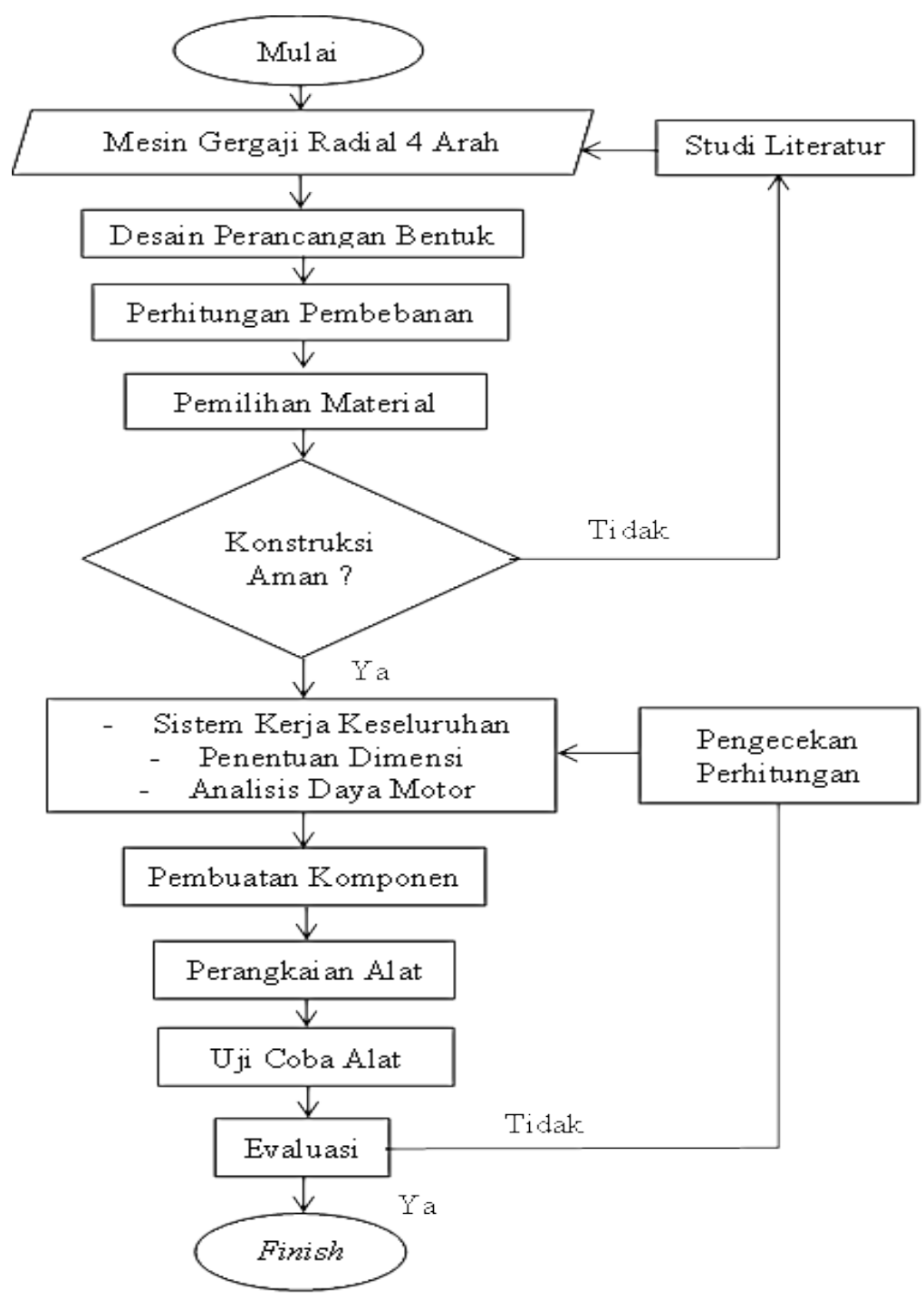

Gambar 1. Diagram metode alir penelitian 


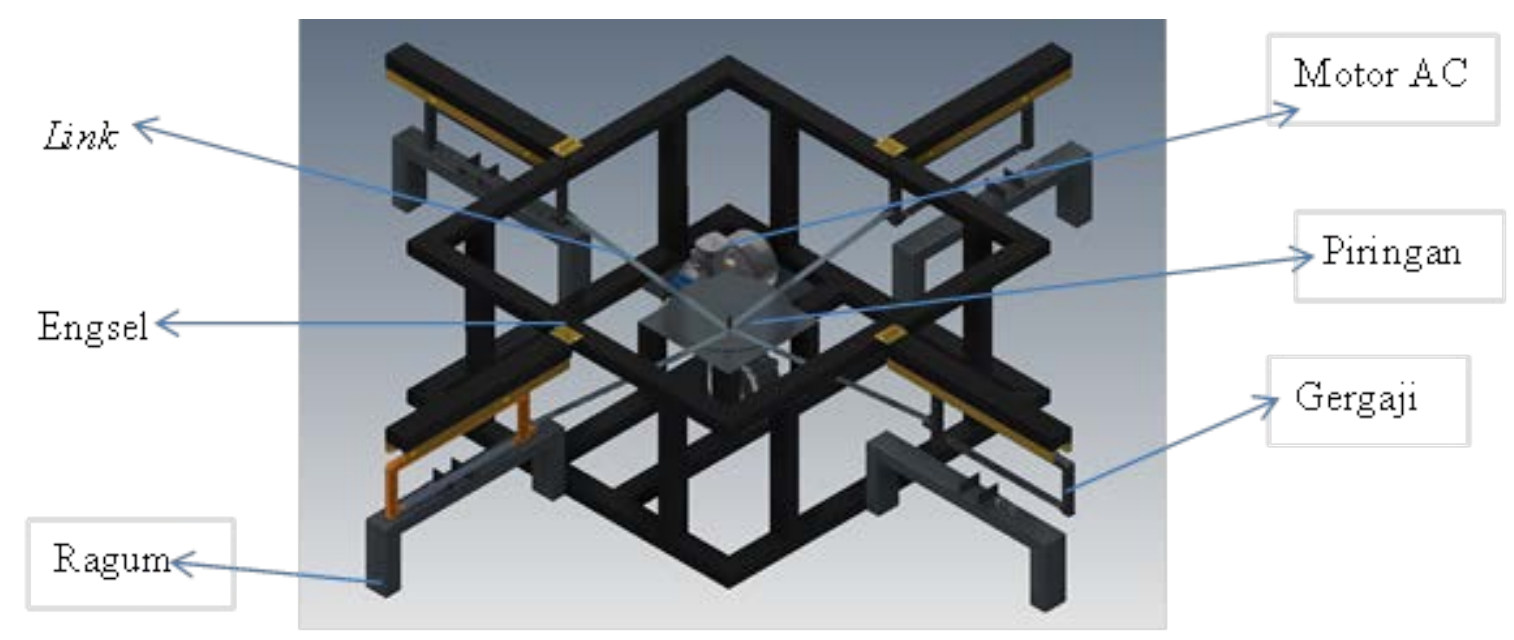

Gambar 2. Mesin gergaji radial empat arah

\section{HASIL DAN PEMBAHASAN}

Berdasarkan data dari referensi, didapat :

Jenis Kayu

Dimensi kayu

$\tau$ (keteguhan belah kayu)

kecepatan putaran motor
: Kayu Sengon

: $50 \mathrm{~mm}$ x $50 \mathrm{~mm}$ x $600 \mathrm{~mm}$

: $3,64 \mathrm{~kg} / \mathrm{mm}$

: $90 \mathrm{rpm}$

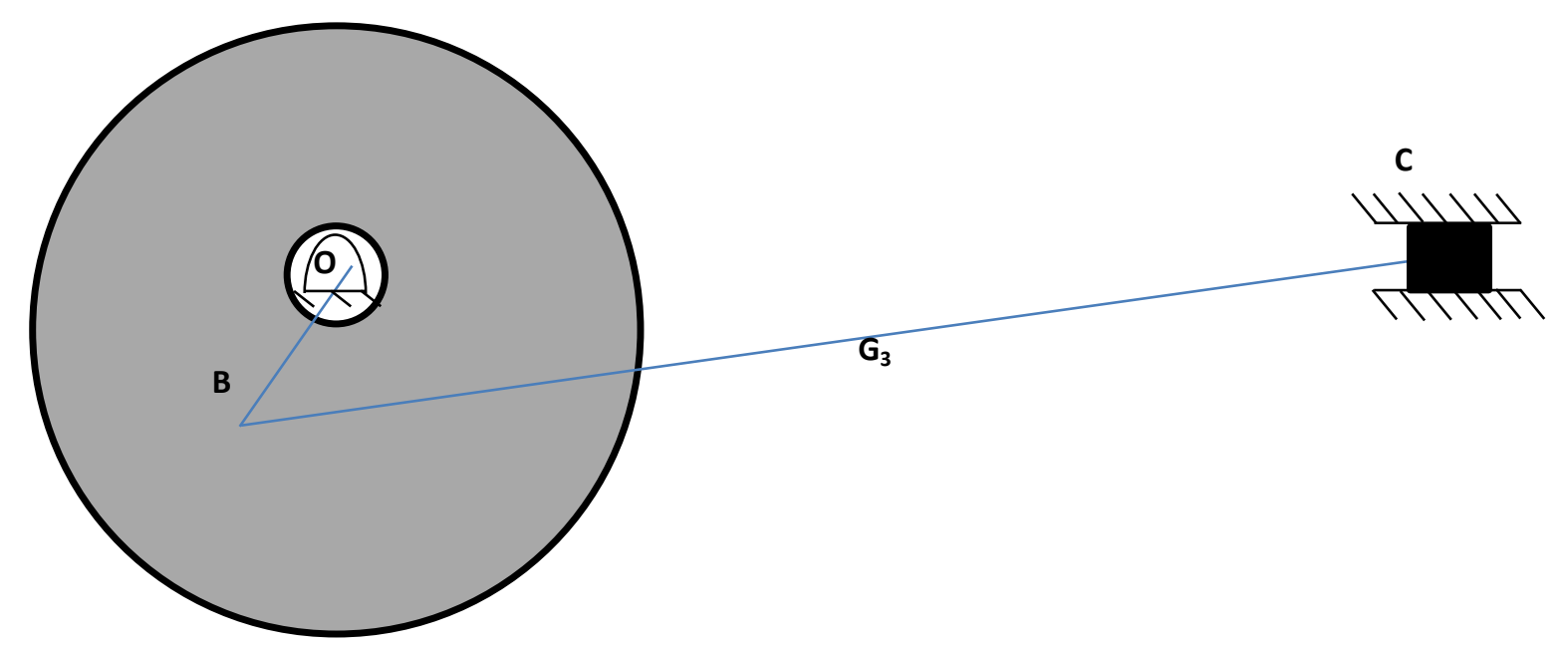

Gambar 3. Mekanisme engkol luncur

Keterangan:

- Piringan berputar searah jarum jam dan gergaji bergerak ke kiri secara translasi

- Ukuran barang asli diperkecil pada gambar 5

- Asumsi gergaji bergerak ke kiri secara translasi

- $\mathrm{O}_{2} \quad=$ link 1 (ground)

- $\mathrm{B} \quad=\operatorname{link} 2$ (piringan)

- $\mathrm{C} \quad=\operatorname{link} 4$ (gergaji)

- $0_{2} \mathrm{~B}=100 \mathrm{~mm}$

- $\mathrm{BC}=600 \mathrm{~mm}$ (link 3)

- $\mathrm{BG}_{3}=300 \mathrm{~mm}$ (titik berat) 
1. Poligon Kecepatan (skala $10 \mathrm{~mm}: 0,2 \mathrm{~m} / \mathrm{s}$ )

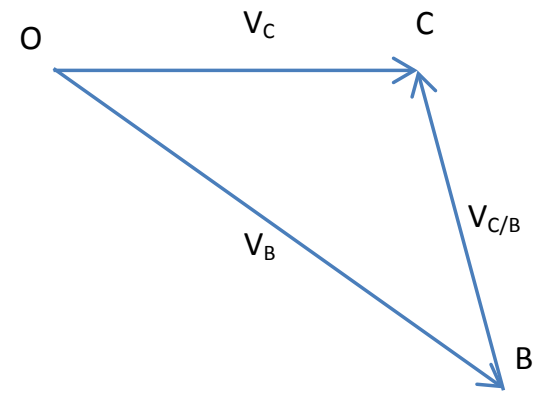

Gambar 4. Poligon Kecepatan

$$
\begin{aligned}
\omega_{2} & =\frac{2 \pi \mathrm{n}}{60} \\
& =\frac{2 \pi 75}{60} \\
& =7,854 \mathrm{~m} / \mathrm{s} \text { (kecepatan sudut piringan) } \\
& =\omega_{2 \times \mathrm{R}} \\
& =\omega_{2 \times \mathrm{OB}} \\
& =7,854 \mathrm{rad} / \mathrm{s} \times 0,1 \mathrm{~m} \\
\mathrm{~V}_{\mathrm{B}} \quad & 0,7854 \mathrm{~m} / \mathrm{s}(\mathrm{Kecepatan} \text { pada titik B) } \\
& =30 \mathrm{~mm} \times 0,2 \mathrm{~m} / \mathrm{s} \\
& =0,6 \mathrm{~m} / \mathrm{s}(\text { Kecepatan pada titik C, didapat dari poligon kecepatan) } \\
\mathrm{V}_{\mathrm{C}} \quad & 23 \mathrm{~mm} \times 0,2 \mathrm{~m} / \mathrm{s} \\
\mathrm{V}_{\mathrm{C} / \mathrm{B}} \quad & 0,46 \mathrm{~m} / \mathrm{s}(\mathrm{kecepatan} \text { titik B relatif terhadap titik C, didapat dari poligon kecepatan) } \\
\omega_{3} \quad & =\frac{V c / b}{B C} \\
& =\frac{0,46 \mathrm{~m} / \mathrm{s}}{0,6 \mathrm{~m}} \\
& =0,76 \mathrm{rad} / \mathrm{s} \text { (Kecepatan sudut link 3, berlawanan arah jarum jam) }
\end{aligned}
$$

2. Poligon Percepatan_(skala $10 \mathrm{~mm}: 1 \mathrm{~m} / \mathrm{s}$ )

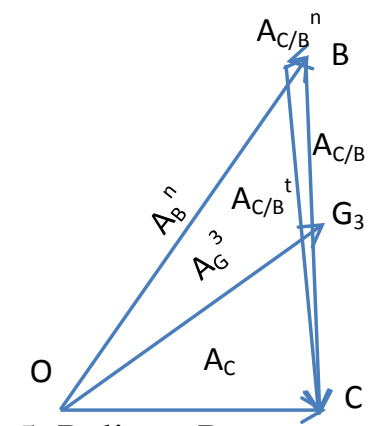

Gambar 5. Poligon Percepatan

$$
\begin{aligned}
\mathrm{A}_{\mathrm{B}}{ }^{\mathrm{n}}=\mathrm{A}_{\mathrm{B}} & =\frac{V b^{2}}{O B} \\
& =\frac{0,7854^{2}}{0,1} \\
& =6,168 \mathrm{~m} / \mathrm{s}^{2} \text { (percepatan pada titik B) } \\
\mathrm{A}_{\mathrm{C} / \mathrm{B}}{ }^{\mathrm{n}} \quad & =\frac{V c / b^{2}}{B C} \\
& =\frac{(0,46 \mathrm{~m} / \mathrm{s})^{2}}{0,6 \mathrm{~m}} \\
& =0,352 \mathrm{~m} / \mathrm{s}^{2} \text { (percepatan normal pada titik B relatif terhadap C, didapat dari poligon) }
\end{aligned}
$$




$$
\begin{aligned}
\mathrm{A}_{\mathrm{C} / \mathrm{B}}{ }^{\mathrm{t}}= & 52 \mathrm{~mm} \times 1 \mathrm{~m} / \mathrm{s}^{2} \\
= & 5,2 \mathrm{~m} / \mathrm{s}^{2} \text { (percepatan tangensial pada titik B relatif terhadap C, didapat dari } \\
& \text { poligon) } \\
\mathrm{A}_{\mathrm{C} / \mathrm{B}} \quad & 51 \mathrm{~mm} \times 1 \mathrm{~m} / \mathrm{s}^{2} \\
= & 5,1 \mathrm{~m} / \mathrm{s}^{2} \text { (percepatan total titik B relatif terhadap C, didapat dari poligon) } \\
\mathrm{A}_{\mathrm{C}} \quad & 35 \mathrm{~mm} \times 1 \mathrm{~m} / \mathrm{s}^{2} \\
= & 3,5 \mathrm{~m} / \mathrm{s}^{2} \text { (percepatan pada titik C, didapat dari poligon) } \\
= & \frac{A c / b^{t}}{B C} \\
\alpha_{3} & \frac{5,2 \frac{m}{s^{2}}}{0,6 \mathrm{~m}} \\
= & 8,67 \mathrm{rad} / \mathrm{s}^{2} \\
= & 42 \mathrm{~mm} \times 1 \mathrm{~m} / \mathrm{s}^{2} \\
= & 4,2 \mathrm{~m} / \mathrm{s}^{2}(\text { percepatan pada titik berat link 3, didapat dari poligon) }
\end{aligned}
$$

3. Gaya Inersia (skala offset $10 \mathrm{~mm}: 50 \mathrm{~mm}$ )

$$
\begin{aligned}
\mathrm{f}_{3} & =\mathrm{m}_{3} \times \mathrm{AG}_{3} \\
& =1 \mathrm{~kg} \times 4,2 \mathrm{~m} / \mathrm{s}^{2} \\
& =4,2 \mathrm{~N}(\text { gaya inersia pada link 3) } \\
\mathrm{f}_{4} & =\mathrm{m}_{4} \times \mathrm{AG}_{4} \\
& =1,3 \mathrm{~kg} \times 3,5 \mathrm{~m} / \mathrm{s}^{2} \\
& =4,55 \mathrm{~N}(\text { gaya inersia pada link } 4) \\
\mathrm{I}_{3} & =\frac{1}{12} \mathrm{~m}\left(\mathrm{a}^{2}+\mathrm{b}^{2}\right) \\
& =\frac{1}{12} 1 \mathrm{~kg}\left\{(0,5 \mathrm{~m})^{2}+(0,034 \mathrm{~m})^{2}\right\} \\
& =0,021 \mathrm{kgm}^{2}(\text { Inersia pada link 3) } \\
& =\frac{I_{3} \omega_{3}}{m_{3} A G_{3}} \\
& =\frac{0,021 \mathrm{kgm}^{2} \times 8,67^{2} \mathrm{rad} / \mathrm{s}^{2}}{1 \mathrm{~kg}^{2} \times 4,2 \frac{\mathrm{m}}{\mathrm{s}^{2}}} \\
& =0,04335 \mathrm{~m}
\end{aligned}
$$

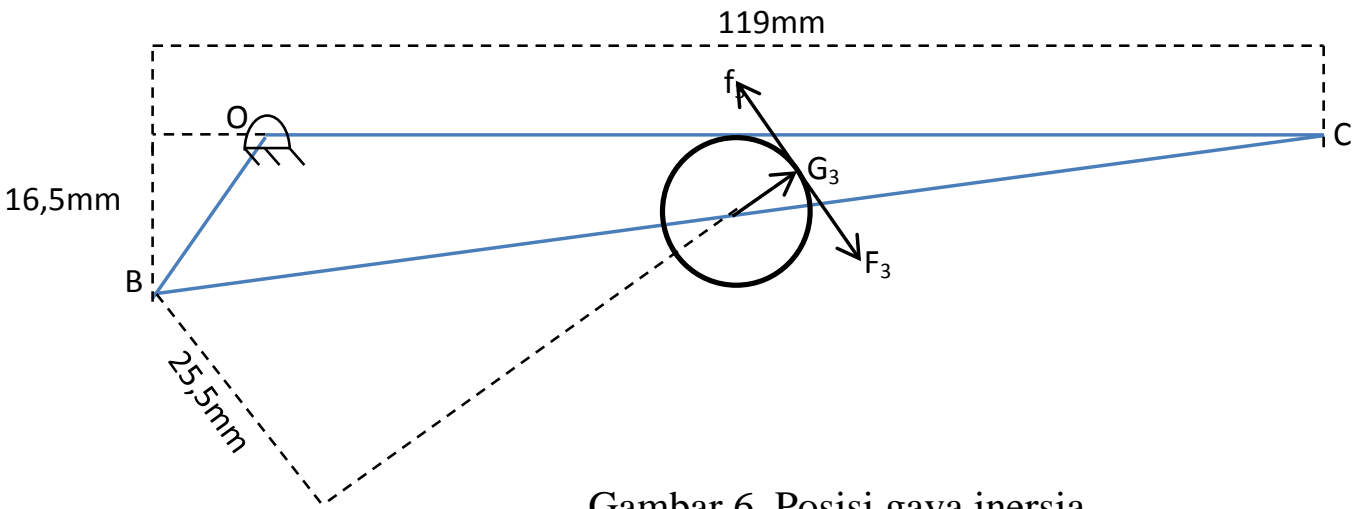

Gambar 6. Posisi gaya inersia

\section{Momen}

$\Sigma \mathrm{MB} \quad=0$

$\mathrm{f}_{3}(25,5 \mathrm{~mm} \times 5)+\left(\mathrm{f}_{4}+\mathrm{F}\right) \times(16,5 \mathrm{~mm} \times 5)+\mathrm{F}_{14}(119 \mathrm{~mm} \times 5)=0$

$4,2 \mathrm{~N} \times 127,5 \mathrm{~mm}+(4,55 \mathrm{~N}+223,17 \mathrm{~N}) \times 82,5 \mathrm{~mm}+\mathrm{F}_{14} \times 595 \mathrm{~mm}=0$

$535,5 \mathrm{Nmm}+18.786,9 \mathrm{Nmm}=-595 \mathrm{mmF}_{14}$

$\mathrm{F}_{14} \quad=\frac{19322,4 \mathrm{Nmm}}{-595 \mathrm{~mm}}$

$\mathrm{F}_{14} \quad=-32,47 \mathrm{~N}$ (karena hasil negatif, maka $\mathrm{F}_{14}$ ke bawah) 
5. Poligon Gaya (skala $10 \mathrm{~mm}: 20 \mathrm{~N}$ )

$$
\begin{aligned}
\mathrm{F}_{23} & =23,2 \times 10 \mathrm{~N} \\
& =232 \mathrm{~N} \\
\mathrm{~F}_{23}=\mathrm{F}_{32} & =\mathrm{F}_{12}=\mathrm{F}_{21}=232 \mathrm{~N}
\end{aligned}
$$

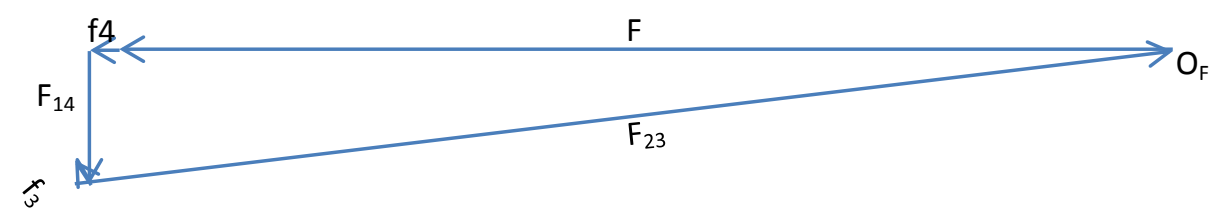

Gambar 5. Poligon Gaya

6. Torsi (terletak pada link 2 atau piringan, skala $10 \mathrm{~mm}: 50 \mathrm{~mm}$ )

$$
\begin{aligned}
\mathrm{h}_{2} & =1,5 \times 50 \mathrm{~mm} \\
& =75 \mathrm{~mm} . \\
\mathrm{T}_{2} & =\mathrm{F}_{32} \times \mathrm{h} \\
& =232 \mathrm{~N} \times 0,075 \mathrm{~m} \\
& =17,4 \mathrm{Nm} \text { (berputar searah jarum jam) } \\
\mathrm{T}_{\text {total }} & =17,4 \mathrm{Nm} \times 4 \\
& =69,6 \mathrm{Nm} .
\end{aligned}
$$

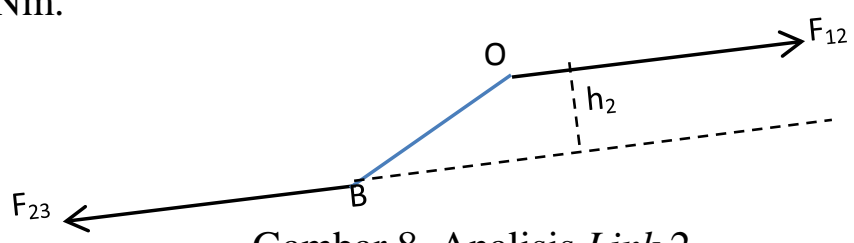

Gambar 8. Analisis Link 2

7. Daya Motor

$$
\begin{aligned}
\mathrm{P} & =\frac{2 \pi n T}{60} \\
& =\frac{2 \pi \times 90 \times 69,6 \mathrm{Nm}}{60} \\
& =546,637 \mathrm{watt}
\end{aligned}
$$

8. Daya Rencana

$$
\begin{aligned}
\mathrm{P}_{\mathrm{d}} & =\mathrm{P} \mathrm{x} \mathrm{f}_{\mathrm{c}} \\
& =546,637 \text { Watt } \times 1,3 \\
& =710,628 \text { Watt }
\end{aligned}
$$

\section{Perhitungan Poros}

Data yang diketahui :

- Putaran yang diinginkan adalah 75rpm

- Daya motor yang digunakan 1,5HP atau 1119watt

$$
\begin{aligned}
\mathrm{T} & =\frac{P \times 60}{2 \pi n} \\
& =\frac{1119 \mathrm{watt} \times 60}{2 \pi \times 75} \\
& =\frac{67140}{471,238} \\
& =142,475 \mathrm{Nm} \\
& =142.475 \mathrm{Nmm} \\
\sigma_{\text {geser }} & =\frac{\tau}{\sqrt{3}}
\end{aligned}
$$




$$
\begin{aligned}
& =\frac{58 \frac{\mathrm{kg}}{\mathrm{mm}^{2}}}{\sqrt{3}} \times 9,81 \mathrm{~m} / \mathrm{s}^{2} \\
& =\frac{568,98}{\sqrt{3}} \\
& =328,5 \mathrm{MPa} \\
\sigma_{\text {izin }} & =\frac{\sigma_{\max }}{S F} \\
& =\frac{328,5 \mathrm{MPa}}{4} \\
& =82,125 \mathrm{MPa} \\
& =82.125 .000 \mathrm{~Pa} \\
\mathrm{~d} & =\sqrt[3]{\frac{16 \times T}{\pi \times \tau}} \\
& =\sqrt[3]{\frac{16 \times 142.475 \mathrm{Nmm}}{\pi \times 82.125 .000 P a}} \\
& =\sqrt[3]{\frac{2279600 \mathrm{Nmm}}{\pi \times 82.125 .000 P a}} \\
& =\sqrt[3]{8,849 \times 10^{-3}} \\
& =0,0206 \mathrm{~m} \\
& =20,6 \mathrm{~mm}
\end{aligned}
$$

Menggunakan rumus poros dengan beban torsi murni, maka didapat diameter poros minimum yang digunakan adalah $20,6 \mathrm{~mm}$. Nilai $58 \frac{\mathrm{kg}}{\mathrm{mm}^{2}}$ didapat dari referensi kekuatan tarik dengan material S45C.

\section{Perhitungan Panjang Rantai}

Data yang diketahui :

- Cp (jarak sumbu poros) $\quad=400 \mathrm{~mm}$

- $\quad$ Pitch (jarak bagi) $\quad=15,875 \mathrm{~mm}$

- $\quad$ Jumlah gigi sproket besar $\left(\mathrm{Z}_{1}\right) \quad=15$ gigi

- Jumlah gigi sproket kecil $\left(Z_{2}\right) \quad=15$ gigi

$$
\begin{aligned}
\text { Lp } & =\frac{Z_{1}+Z_{2}}{2}+2 \mathrm{C}_{\mathrm{p}}+\frac{\left[\left\{Z_{2}-Z_{1}\right\} / 6,28\right]^{2}}{C p} \\
& =\frac{15+15}{2}+2 \times 400 \mathrm{~mm}+\frac{[\{15-15\} / 6,28]^{2}}{400 \mathrm{~mm}} \\
& =\frac{30}{2}+800 \mathrm{~mm}+\frac{0}{400 \mathrm{~mm}} \\
& =15+800 \mathrm{~mm} \\
& =815 \mathrm{~mm}
\end{aligned}
$$

Dengan perhitungan rumus transmisi rantai dan sproket, maka panjang rantai minimum yang digunakan adalah 815mm. Digunakan nomor rantai RS50. 


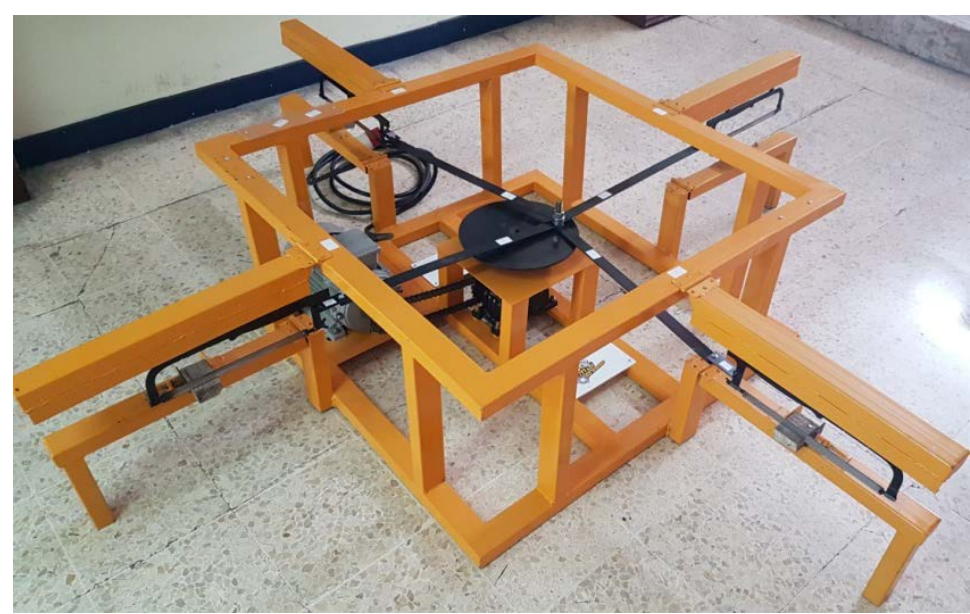

Gambar 9. Prototype mesin gergaji radial 4 arah

\section{KESIMPULAN}

Mesin gergaji radial 4 arah mempunyai sumber penggerak berupa motor listrik AC dengan sistem transmisi berupa rantai dan sproket. Sproket yang digunakan mempunyai rasio 1 : 1 . Wormgear digunakan untuk mereduksi putaran yang dihasilkan oleh motor menggunakan rasio 1 : 10. Mata potong gergaji menggunakan mata potong gergaji kayu dengan mata gigi lurus. Perhitungan daya motor dilakukan untuk mendapatkan daya minimum yang dibutuhkan. Motor listrik yang digunakan mempunyai daya sebesar 1119watt. Torsi total yang terjadi bernilai 69,6N. mesin ini dirancang untuk memotong kayu dengan keteguhan belah maksimum 3,64 $\frac{\mathrm{kg}}{\mathrm{mm}}$.

\section{DAFTAR PUSTAKA}

[1] http://rumahcahaya.com/mesin-gergaji.

[2] Eugene Hecht Frederick J. Buerche, Schaum's Outlines of Theory and Problems of College Physics, tenth edition ed., Lemeda Simarmata, Ed. Indonesia, Jakarta: Erlangga, 2006.

[3] R. C. Hibbeler, "Mechanic of Materials," in Mechanic of Materials. Singapore, Singapore: Prentice Hall, 2011, p. 179.

[4] Brian Kristianto, "Motor DC dan MOTOR AC," April 2011. 